Check for updates

The BMJ

Cite this as: $B M / 2021 ; 373: n 558$ http://dx.doi.org/10.1136/bmj.n558 Published: 06 April 2021

\section{Covid-19: How clinical academic trainees came back to the wards en masse}

\section{When covid-19 first hit the UK, trainees working in clinical academia took the initiative to return to clinical practice and support the NHS’s response to the virus, Abi Rimmer reports.}

\section{Abi Rimmer}

In spring 2020, an estimated 1500+ academic trainees in England-representing more than 90\% of all trainees on the National Institute for Health Research's (NIHR) Integrated Academic Training pathway-returned to clinical duties.

"Academic trainees made up a workforce of at least a couple of thousand people who remobilised to the front line," says Moira Whyte, chair of the UK-wide Clinical Academic Training Forum (CATF), a body that brings together a number of stakeholders involved in academic training.

Almost all of the NIHR clinical lecturers, who were meant to have ringfenced research time, went back to full time clinical work, according to Whyte. "Well over half of people on fellowships just stopped them and went back to clinical work, and even as late as the end of June $75 \%$ of academic trainees were still doing more clinical work than they were meant to be doing."

Whyte thinks that these trainees deserve recognition. "Some people wonder what clinical academics actually do and this is an impressive example of their contribution to service. Many also made contributions to research into covid," she says.

\section{Research skills on the shop floor}

Bill Irish, academic training lead for the Conference of Postgraduate Medical Deans, agrees. "The way that academic trainees responded to the NHS's need in terms of covid was extraordinary," he says.

"Almost to a man or woman they volunteered to work on the NHS front line and there was no requirement for them to do it."

While these trainees helped to backfill hospital roles, their experience of research also meant they had something extra to offer, Irish says.

"One of the big questions has been what is the best way to treat someone who has covid-19," he says. "The people who returned are clinical researchers. They have brilliant skills when it comes to looking at treating people in acute care situations as well as vaccines, and shielding.”

\section{Returning for the second wave}

Together with funders and postgraduate deans from all four nations of the UK, CATF used learning from the first wave of the pandemic to craft a plan in case of a return of covid-19 or for other future pandemics.

Those plans have worked well for the second wave of the virus, allowing individualised discussions between the trainee, their academic institution, and postgraduate deanery about whether academic trainees should volunteer for additional clinical duties.

A key concern for CATF now is how these trainees will be supported to complete their research and to progress their academic careers, Whyte says.

"These trainees are crucial to the future of the NHS. They did the right thing [by returning to practice] but it has been in many cases disruptive to their career plans. We have to make sure they are given the time and resource to get back on track."

As trainees began to return to their research roles from direct patient contact, it became clear there wasn't a one-size-fits-all solution for supporting them, Whyte says. "Although it might look like they went back to the NHS for a few months and that is just a blip in a career, the effects will vary according to what research they do."

She called on funders and universities to recognise that and to offer support for these trainees. "Funders have been receptive about how they can make allowances for these trainees when they apply for their next fellowship.... Many funders have agreed to change their application form so applicants can explain the impact covid-19 has had on their career-for example, why their publications are delayed or why they don't have as much preliminary data as they might have wanted."

While for some, covid-19 has presented new opportunities, for others it has been disruptive. Says Whyte, "For people planning really long-term experiments with mice or stem cell populations, as well as those doing clinical trials, these are disruptions that will carry on for a year or more."

Clinical academic trainees' experiences of the pandemic

\section{Alison Berne}

I'm undertaking a Cancer Research UK funded PhD in cancer genomics at Barts Cancer Institute. Prior to that I was a trainee in oncology in the north central Thames area. When the pandemic happened there wasn't an obvious hospital for me to go back to. Everybody was going onto a covid rota and it made more sense for me to do that at my local hospital, Milton Keynes, so I contacted the medical director and within a week I had started.

The first covid ward had been set up a few weeks before I joined. They were receiving all of the potential covid patients from the emergency department so we were seeing patients who were incredibly short of breath with oxygen requirements; some of whom were dying, and some who needed to be escalated to the ICU. 
I then moved to the confirmed covid ward. Here the patients were either pretty stable and getting better, or getting worse and dying.

Within two weeks I realised that I had not lost my clinical acumen and it was all coming back. But it was important to be well supported.

I'm a silver linings person. For me the time working on the covid wards provided an opportunity for a clinical pitstop halfway through my research. It made me more up to date and much more confident. I met people and I learned things that I think will be beneficial for the rest of my career and my training.

\section{Mark Thomas}

Before the pandemic my NIHR clinical lecturer post meant I spent $50 \%$ of my time doing research and the other half of my week as a cardiology registrar. At the end of March 2020, instead of my normal clinical and academic split, I moved into full time clinical work.

I worked on the cardiology ward before I volunteered to be redeployed as an intensive care registrar on the covid unit. I did that for about six weeks or so and went back to splitting my time between academic and clinical work in June.

When I was doing full time clinical work I kept just my essential academic work going, doing as much as I could. In a way that meant life became simpler because I was mostly focusing on clinical work. I would do 12 hours of clinical work, for example, and then work was over. In some ways it was a simpler life-busy, but simpler.

The redeployment of doctors, like me, meant that on the ICU we had a real mix of different specialities and skills. There was a lot of enthusiasm and a buzz working there. It meant that the patients received really good care.

As trainees we learnt so much because the senior support was there. We also got on well as a team and there was a real sense of camaraderie when we were working.

It was a bizarre experience overall. But as a doctor I was proud to see the true strengths of the NHS.

\section{Emma Wall}

I am an infectious diseases physician and post-doctoral clinical research fellow at the Francis Crick Institute. During the first national lockdown I took a leave of absence from my fellowship.

I decided to return to clinical practice because-and this is going to sound crazy to anyone who isn't an infectious diseases doctor-because I missed out on working with Ebola patients. Because I was pregnant at the time, I wasn't allowed to be deployed to west Africa and I wasn't allowed to work in the UK. I was cross about that because I've been teaching medical students and junior doctors how to manage pandemics for years. I have always wanted to use my skills in infectious diseases and acute medicine during an outbreak of a new disease.

When it became clear that coronavirus was coming to the UK I spoke to colleagues from University College (London) Hospital (UCLH) and asked what their plans were. They said that they were calling back everyone from academia who could leave their jobs because they needed all hands on deck. It was a very uncertain time in the hospital, we did not know how many cases we would receive, or how sick they would be. It looked like the institute was going to close so I asked them to put me on unpaid leave rather than furlough, and I went back to the hospital.

Before my fellowship started I had worked at UCLH on and off for more than 10 years, and recently been a consultant in acute medicine in the same unit so I knew all the nurses, the team, and the system, but what I didn't know was how it was going to run with covid-19.

The way the hospital facilitated change in real time was extraordinary. They had been debating for years about whether the stroke unit at UCLH needed to move to the National Hospital for Neurology and Neurosurgery at Queen's Square, and then literally in five days it was done.

The unit was turned into a covid hub for patients requiring treatment with continuous positive airway pressure, showing that when the hospital really had to do something, all of the politics and the arguing could be put to one side and things could happen very fast. I hope some of that dynamism, especially among the senior clinical management, stays.

There was hospital wide collection of data on covid-19 patients for clinical trials, including for the Randomised Evaluation of Covid-19 Therapy (RECOVERY) trial. The research studies I was involved in also happened much more quickly than they usually would. Usually someone has an idea for a research study, there are meetings, and then they write a protocol which has to be approved-much of those processes were waived or expedited.

Competing interests: none.

Provenance and peer review: not commissioned; not externally peer reviewed.

This article is made freely available for use in accordance with BMJ's website terms and conditions for the duration of the covid-19 pandemic or until otherwise determined by BMJ. You may use, download and print the article for any lawful, non-commercial purpose (including text and data mining) provided that all copyright notices and trade marks are retained. 